\title{
Identifikasi Religiusitas Siswa di SMA Adhyaksa 1 Jambi
}

\author{
Corry Mandriesa ${ }^{1}$ \\ ${ }^{1}$ Sekolah Menengah Atas Adhyaksa 1 Kota Jambi, Jambi, Indonesia
}

\begin{tabular}{l}
\hline \hline Article Info \\
\hline Article history: \\
Received Des 21, 2019 \\
Revised Des 27, 2019 \\
Accepted Jan 1, 2020 \\
\hline
\end{tabular}

\section{Keywords:}

Belajar

Religiusitas

Siswa

\begin{abstract}
ABSTRAK
Tujuan Penelitian: Tujuan penelitian ini adalah untuk mengetahui bagaimana religiositas siswa di SMA Adhyaksa 1 Jambi.

Metodologi: Jenis penelitian ini adalah kuantitatif dengan instrumen kuesioner dan jumlah responden 140 siswa SMA Adhyaksa 1 Jambi dengan teknik pengambilan sampel yaitu random sampling. Teknik analisis data yang digunakan adalah analisis deskriptif dengan menghadirkan nilai ratarata, media, mode, maksimum dan minimum.

Temuan utama: Hasil penelitian ini diketahui berarti rata-rata 190,5571, nilai median 191,0000 dan maksimum minimum 225 dan 147 dan persentase agama siswa di SMA Adhyaksa 1 Jambi pada 84,3\% dikategorikan baik. Berdasarkan hasil ini, siswa SMA Adhyaksa 1 Jambi di diketahui memiliki religiusitas yang baik.

Keterbaruan penelitian: Keterbaharuan dari penelitian ini ialah belum adanya penelitian yang mengkaji suatu permasalahan pendidikan berdasarkan aspek keagamaan di SMA Adhyaksa 1 Kota Jambi . Penilaian agama ini diharapkan dapat meningkatkan pemahaman siswa terkait dengan ajaran agama yang mereka anut, sehingga siswa dapat mempraktikkannya dalam mempelajari Fisika dan kehidupan sehari-hari.
\end{abstract}

This is an open access article under the $\mathrm{CC} B Y-N C$ license

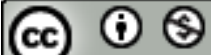

\section{Corresponding Author:}

Cory Mandriesa,

SMA Adhyaksa 1 Kota Jambi, Jambi, Indonesia

Email: corrym@gmail.com

\section{PENDAHULUAN}

Pendidikan memiliki peran yang sangat penting dalam pengembangan manusia yang lengkap. Oleh karena itu pendidikan sangat perlu dikembangkan dari berbagai ilmu, karena pendidikan yang berkualitas dapat meningkatkan kecerdasan suatu bangsa. Pendidikan adalah proses meningkatkan kualitas hidup, serta memperoleh dan menanamkan keterampilan yang dilakukan oleh siswa [1]. Menurut [2], Pendidikan adalah upaya yang dilakukan untuk menumbuhkan dan mengembangkan potensi sumber daya manusia, terutama siswa dengan membimbing dan memfasilitasi kegiatan belajar mereka. Pendidikan memainkan peran penting dalam meningkatkan kualitas sumber daya manusia. Pendidikan dinilai telah mencapai tujuan apabila lulusan yang dihasilkan mampu berdaya saing dengan mutu lulusan yang lain [3]. Pendidikan memegang peranan penting dalam kehidupan manusia [4]. Menurut [5], tujuan pendidikan nasional adalah untuk mengembangkan potensi peserta didik sehingga mereka menjadi individu Indonesia dengan iman dan takut akan Tuhan, moral yang mulia, kesehatan yang baik, pengetahuan yang hebat, kompetensi, kreativitas, dan kemandirian, dan menjadi individu yang demokratis dan warga negara yang bertanggung jawab. Selain itu, sesuai dengan Undang-Undang Republik Indonesia Nomor 20 Tahun 2003 pasal 3, pendidikan nasional 
bertujuan untuk mengembangkan potensi siswa untuk menjadi manusia yang percaya dan takut akan Tuhan Yang Maha Esa, memiliki yang mulia, sehat, berpengetahuan luas, mampu, mampu, mampu , kreatif, mandiri, dan menjadi warga negara yang demokratis dan bertanggung jawab. Kerangka Kualifikasi Nasional (KKNI) merupakanrumusan kemampuan yang dinyatakan dengan istilah capaian pembelajaran [6].

Salah satu cara untuk mendidik siswa menjadi orang yang beriman, beriman, berakhlak mulia, berpengetahuan luas, kreatif, mandiri dan bertanggung jawab adalah menerapkan pendidikan karakter bagi siswa di sekolah. Pendidikan karakter adalah proses menciptakan lingkungan sekolah yang dalam hal ini mampu membantu siswa dan pengembangan karakter yang baik, tanggung jawab, dan karakter mengajar. Menurut [7], pendidikan karakter adalah sistem yang menanamkan nilai-nilai karakter kepada siswa yang mencakup komponen pengetahuan, kesadaran atau kehendak, dan tindakan untuk melaksanakan nilai-nilai ini, baik terhadap Tuhan Yang Maha Esa (YME), diri sendiri, orang lain, lingkungan, dan kebangsaan sehingga kita adalah manusia. Secara khusus, pendidikan karakter berdasarkan nilai-nilai agama mengacu pada nilai-nilai dasar yang ditemukan dalam agama.

Pendidikan karakter pertama yang harus diterapkan kepada siswa adalah agama. Karakter keagamaan ini sangat dibutuhkan oleh siswa dalam menghadapi perubahan zaman dan degradasi moral, dalam hal ini siswa diharapkan dapat memiliki dan berperilaku baik dan buruk berdasarkan ketentuan dan ketentuan agama. Religius adalah sikap atau perilaku yang mematuhi semua perintah Tuhan dan menjauhi semua larangan Tuhan. Sikap di sini terkait dengan selalu bersyukur atas apa yang telah Tuhan berikan tanpa mengeluh dan mengetahui larangan Tuhan. Perilaku terkait dengan toleransi dengan agama lain, menuju pelaksanaan ibadah agama lain, serta hidup rukun bersama, saling menghormati dan saling membantu [8]. Menurut [9], meskipun kebebasan beragama, toleransi, netralitas negara dan kebebasan untuk mempraktikkan keyakinan seseorang adalah prinsip-prinsip inti masyarakat Eropa. Selain itu, di Eropa umumnya studi agama non-pengakuan mencerminkan kelembagaan di negara-negara di mana pendidikan agama adalah mata pelajaran yang diajarkan dalam berbagai bentuk dan format di sekolah-sekolah umum dan di mana subjek secara langsung berkontribusi pada pelatihan guru [10]. When students effectively learn by experimentation, students' science process skills will increase [11]. Agama memiliki pengaruh yang baik terhadap sikap dan perilaku manusia. Seseorang akan dengan mudah menyesuaikan diri dengan orang lain jika ia memiliki nilai-nilai agama atau agama yang tinggi dan tidak akan berperilaku menyimpang seperti yang kita lihat pada remaja saat ini. Di antara remaja saat ini sering dijumpai adanya perilaku menyimpang. Perilaku menyimpang adalah hasil dari proses sosialisasi yang tidak sempurna. Munculnya perilaku mendadak itu sendiri disebabkan oleh rendahnya tingkat siswa agama.

Agama sangat berpengaruh terhadap sikap yang ditunjukkan oleh siswa. Menurut [12], menyatakan bahwa tingkat religiusitas pada remaja akan mempengaruhi perilaku (sikap) mereka. Sehingga siswa yang religius tinggi akan menunjukkan sikap positif, dan sebaliknya jika siswa yang religius rendah maka siswa tersebut akan menunjukkan sikap negatif. Sikap dalam belajar sangat penting, seperti halnya sikap dalam belajar [13]. Salah satu mata pelajaran yang membuat siswa menunjukkan sikap positif dan negatif adalah Fisika. Fisika sebenarnya adalah salah satu mata pelajaran yang dianggap berat dan dihindari oleh beberapa siswa karena memerlukan ketekunan, keseriusan dan banyak latihan [14]. Siswa yang senang belajar fisika akan tertarik untuk meningkatkan waktu untuk belajar fisika, mencari tahu pemecahan masalah fisika dan menambah pengetahuan tentang fisika. Fisika merupakan pembelajaran dengan ilmu pengetahuan yang membahas gejala-gejala dan sifat-sifat pada benda yang beradadi alam [15]. Namun dalam kenyataannya tidak banyak siswa yang menyukai fisika karena mereka pikir fisika itu sulit, sehingga kenikmatan fisika siswa dikategorikan cukup. Students who have a positive attitude toward certain lessons tend to be more diligent in learning so as to achieve satisfactory results [13]. Physics practicum is an activity that aims to ensure the principles and laws of physics by experimenting in the laboratory [14]. Selama ini kemampuan siswa untuk dapat menyelesaikan masalah masih kurang diperhatikan oleh sebagian guru, akibatnya manakala siswa menghadapi masalah, banyak siswa yang tidak dapat menyelesaikan masalahnya dengan baik [15]. Fisika abstrak dan menggunakan banyak rumus membuat minat siswa dalam belajar rendah sehingga siswa berperilaku negatif. Akibatnya, hasil belajar fisika siswa menurun [16]. So, learning resources are one of the factors that make students understand the concepts and material well [17]. Kerjasama sangat dibutuhkan dalam bermasyarakat, mengingat manusia adalah makhluk social [18]. Sehingga untuk menunjang sebuah profesional guru, calon guru harus mempunyai berbagai kemampuan yaitu kemampuan knowledge of teaching dan knowledge of teacher [19]. The success of learning itself is not only assessed by the teacher's teaching method, but needs to be supported by learning methods, teaching aids, and resources [20]. The success of the learning process is influenced by the quality and way of teaching a teacher $[21,22]$.

Hambatan yang dihadapi dalam meningkatkan sikap siswa dalam belajar fisika adalah kebosanan dan pandangan negatif siswa terhadap fisika. Sikap senang siswa terhadap sains dapat ditunjukkan bagaimana siswa bersikap terbuka dan semangat terhadap mata pelajaran sains di dalam atau pun luar kelas [23]. Sikap 
positif terhadap pembelajaran fisika sangat membantu dalam memahami pelajaran. Dengan demikian, guru perlu mengembangkan pembelajaran aktif dan dapat meningkatkan minat dan rasa ingin tahu siswa sehingga sikap positif siswa akan meningkat dalam pembelajaran [24][25]. Ini berarti bahwa sebagai seorang pendidik harus dapat membuat siswa berperilaku positif dalam pembelajaran Fisika, sehingga hasil belajar siswa meningkat dan apa yang telah diajarkan dapat diterima dan diterapkan oleh siswa dengan baik. Tujuan dari penelitian ini adalah untuk mengetahui deskripsi agama siswa dalam pembelajaran fisika di SMA tepatnya di SMA Adhyaksa 1 Jambi.

\section{METODE PENELITIAN}

Metode penelitian yang digunakan dalam penelitian ini ialah kuantitatif. Penelitian kuantitatif adalah penelitian yang digunakan untuk menjawab masalah melalui teknik pengukuran yang cermat terhadap variabel-variabel tertentu. Analisis kuantitatif berkaitan dengan data dalam bentuk angka dan menggunakan operasi matematika untuk menyelidiki sifat-sifat mereka. Tingkat pengukuran yang digunakan dalam pengumpulan data nominal, ordinal, interval, dan rasio, merupakan faktor penting dalam memilih jenis analisis yang berlaku, seperti halnya jumlah kasus yang terlibat. Statistik adalah nama yang diberikan untuk jenis analisis ini, dan didefinisikan dalam pengertian ini sebagai berikut: mengukur, membuat perbandingan, memeriksa hubungan, membuat ramalan, menguji hipotesis, menyusun konsep dan teori, mengeksplorasi, mengendalikan, dan menjelaskan [26].

Sampel adalah sekelompok individu, item, 6 atau peristiwa yang mewakili karakteristik kelompok yang lebih besar dari mana sampel diambil. Menguji sampel, terutama dalam studi kuantitatif, dapat memungkinkan peneliti untuk membuat kesimpulan tentang kinerja kelompok yang lebih besar, yang dikenal sebagai populasi. Proses memilih sampel dikenal sebagai sampling [27][28]. Sampel dalam penelitian ini adalah 140 siswa SMA Adhyaksa 1 Jambi di Yogyakarta. Teknik pengambilan sampel yang digunakan adalah random sampling. Pengambilan sampel acak juga dikenal sebagai probabilitas pengambilan sampel. Pengambilan sampel acak adalah di mana setiap anggota populasi memiliki probabilitas yang sama untuk menjadi sampel penelitian. Teknik ini dianggap sebagai teknik terbaik untuk mendapatkan sampel yang representatif [29].

Pengumpulan data dalam penelitian ini menggunakan kuesioner. Kuesioner yang didefinisikan (subset dari penelitian survei) sebagai "instrumen tertulis apa pun yang menghadirkan responden dengan serangkaian pertanyaan atau pernyataan yang mereka harus bereaksi baik dengan menuliskan jawaban mereka atau memilih mereka di antara jawaban yang ada [30] Dalam penelitian ini, sebuah Kuisioner dibagikan dengan pilihan jawaban atas pernyataan dalam bentuk skala likert, yaitu SS (Sangat Setuju), S (Setuju), N (Netral), TS (Tidak Setuju) dan STS (Sangat Tidak Setuju) dengan 49 pernyataan. Indikator agama ditunjukkan pada tabel 1.

Tabel 1. Indikator nilai religiusitas siswa

\begin{tabular}{clc}
\hline Variabel & Indikator & Item \\
\hline \multirow{5}{*}{ Religiusitas } & Praktek & 10 \\
& Cinta & 5 \\
& Perlindungan & 5 \\
& Kepercayaan & 5 \\
& Kepercayaan & 8 \\
& Ketulusan & 5 \\
\hline
\end{tabular}

Analisis data dalam penelitian ini adalah analisis deskriptif. Statistik deskriptif menggunakan dan metode grafis untuk mencari pola dalam kumpulan data, untuk meringkas informasi yang diungkapkan dalam kumpulan data, dan untuk menyajikan informasi dalam bentuk yang dapat digunakan individu untuk membuat keputusan. Tujuan utama dari statistik deskriptif adalah untuk mendeskripsikan kumpulan data. Dengan demikian, kelas statistik deskriptif mencakup pengukuran numerik (mis. Median) dan tampilan grafis data (mis. Diagram lingkaran atau grafik batang) [31][32]. Dalam analisis deskriptif, data yang disajikan adalah dalam bentuk rata-rata, median, standar deviasi, nilai maksimum dan minimum.

\section{HASIL DAN PEMBAHASAN}

Keterbaharuan dari penelitian ini ialah belum adanya penelitian yang mengkaji suatu permasalahan pendidikan berdasarkan aspek keagamaan di SMA Adhyaksa 1 Kota Jambi . Penilaian agama ini diharapkan dapat meningkatkan pemahaman siswa terkait dengan ajaran agama yang mereka anut, sehingga siswa dapat mempraktikkannya dalam mempelajari Fisika dan kehidupan sehari-hari. 
Religiusitas siswa adalah perilaku yang mematuhi aturan menurut agama, saling menghormati perbedaan agama dan lainnya. Karakter keagamaan ini sangat penting dalam kehidupan setiap individu dalam mengetahui setiap aturan dan larangan yang telah diatur oleh agama. Selain itu, agama sangat dibutuhkan oleh siswa dalam menghadapi perubahan zaman, dalam hal ini siswa diharapkan dapat memiliki dan berperilaku baik. Nilai-nilai agama siswa di SMA Adhyaksa 1 Jambi dapat dilihat dari hasil kuesioner yang telah dibagikan dengan hasil seperti tabel 2.

Tabel 2. Statistik Deskriptif variabel agama siswa di SMA Adhyaksa 1 Jambi

\begin{tabular}{|c|c|c|c|c|c|c|c|c|}
\hline \multicolumn{4}{|c|}{ Classification } & \multirow{2}{*}{ Mean } & \multirow{2}{*}{ Median } & \multirow{2}{*}{ Min } & \multirow{2}{*}{ Max } & \multirow{2}{*}{$\%$} \\
\hline School & Interval & Category & Total & & & & & \\
\hline SMA & $49.0-88.2$ & Sangat Tidak Baik & 0 & \multirow{5}{*}{190.5} & \multirow{5}{*}{191.00} & \multirow{5}{*}{147.0} & \multirow{5}{*}{225.0} & 0 \\
\hline Adhyaksa 1 & $88.3-127.4$ & Tidak Baik & 0 & & & & & 0 \\
\hline \multirow[t]{4}{*}{ Jambi } & $127.5-166.6$ & Cukup & 6 & & & & & 4.3 \\
\hline & $166.7-205.8$ & Baik & 118 & & & & & 84.3 \\
\hline & $205.9-245.0$ & Sangat Baik & 16 & & & & & 11.4 \\
\hline & Total & & 140 & & & & & 100 \\
\hline
\end{tabular}

Pada tabel 2 dapat digambarkan religiositas siswa terhadap mata pelajaran Fisika di SMA Adhyaksa 1 Jambi memiliki nilai rata-rata 190,5571, nilai rata-rata 191,0000 dan maksimum minimum 225 dan 147. Selain itu dari tabel 1 juga dapat dijelaskan bahwa agama siswa terhadap mata pelajaran Fisika di SMA Adhyaksa 1 Jambi adalah kategori yang paling dominan dengan jumlah responden baik sebanyak 118 siswa dan persentase $84,3 \%$. Selanjutnya, Berkatgeori sangat baik dengan 16 responden dan persentase $11,4 \%$. untuk yang terakhir ini cukup dengan jumlah responden 6 siswa dan persentase 4,3\%. Hasil ini menunjukkan bahwa siswa agama di SMA Adhyaksa 1 Jambi dikategorikan BAIK.

Menurut Kajavinthan [33][34] Agama adalah kekuatan sosial yang luas dan signifikan. Doktrin agama mungkin berbeda dan kegiatan berdasarkan ini mungkin berbeda tetapi agama itu sendiri telah menjadi faktor dominan dalam kehidupan manusia. Praktik-praktik keagamaan mewarnai kehidupan sosial dan ekonomi manusia. Pengaruh agama memiliki pengaruh besar pada sikap seseorang, Menurut [35][36] Religiusitas memiliki pengaruh yang baik pada sikap dan perilaku manusia dan religiusitas merupakan nilai penting dalam struktur kognitif individu yang dapat mempengaruhi perilaku individu. Semakin tinggi sikap religiusitas seseorang, itu akan meminimalkan tingkat kecenderungan untuk berperilaku menyimpang atau perilaku yang ditentang oleh norma-norma agama. Sehingga dapat dilihat bahwa sikap siswa di SMA Adhyaksa 1 Jambi juga dikategorikan baik, hal ini ditunjukkan oleh siswa agama yang baik.

Religus itu sendiri meliputi perdamaian, toleransi, penghormatan terhadap perbedaan agama dan kepercayaan, keteguhan, kepercayaan diri, kerja sama antara penganut agama dan kepercayaan, antibuli dan kekerasan, persahabatan, ketulusan, tidak memaksakan kehendak, mencintai lingkungan, melindungi yang kecil dan pengecualian. Itu karena agama ini diperlukan untuk menjalankan kehidupan ini. Selain itu, kepercayaan agama dapat memberikan motivasi yang baik untuk apa pun yang ingin Anda lakukan. Dari apa yang diketahui bahwa siswa agama di SMA Adhyaksa 1 Jambi baik, sehingga menunjukkan bahwa siswa termotivasi untuk melakukan sesuatu yang baik. Banyak efek dari sikap religius pada seseorang, sikap atau perilaku yang ditunjukkan seseorang, kita akan tahu betul jika Anda tahu agama seseorang.

\section{KESIMPULAN}

Penelitian ini telah meneliti bagaimana religiusitas siswa di SMA Adhyaksa 1 Jambi, dari hasil yang diperoleh, diketahui bahwa religiusitas siswa di SMA Adhyaksa 1 Jambi dikategorikan baik dengan persentase $84,3 \%$. Religiusitas adalah perilaku yang mematuhi aturan menurut agama, menghormati perbedaan agama, rasa saling percaya, tidak memaksakan kehendak, cinta terhadap lingkungan, dan ketulusan dalam melakukan apa pun. Agama mempengaruhi kedua sikap yang akan ditunjukkan seseorang, setiap individu yang memiliki religiusitas tinggi juga akan menunjukkan sikap yang baik. Dan sebaliknya, setiap individu yang beragama rendah akan menunjukkan sikap yang tidak sesuai dengan aturan dan norma agama.

\section{UCAPAN TERIMA KASIH}

Kami ucapkan terima kasih kepada kepala sekolah dan guru-guru SMA Adhyaksa 1 Jambi Indonesia, yang telah memberi kami kesempatan untuk bekerja sama. Juga, kami ingin mengucapkan terima kasih kepada semua siswa/i SMA Adhyaksa 1 Jambi, Indonesia, telah berpartisipasi dalam penelitian ini. 


\section{REFERENSI}

[1] Kurniawan, D.A., Astalini, Anggraini. L. "Evaluasi Sikap Siswa Smp Terhadap Ipa Di Kabupaten Muaro Jambi" Jurnal Ilmiah DIDAKTIKA. 19(1), 124-139. 2018.

[2] Syamsuriyanti \& Sukirno. "Faktor Determinan Profesionalisme Guru". Jurnal Kependidikan. 2(1). Hal. 56-67. 2018.

[3] A. timan Darmaji, Supriyanto, "Sistem Penjaminan Mutu Internal Sekolah Untuk Meningkatkan Mutu Lulusan," vol. 3, no. 2000, pp. 130-137, 2019.

[4] Syamsudin, A., Budiyono, B., \& Sutrisno, S. "Model of affective assessment of primary school students". Research and Evaluation in Education, 2(1), 25. 2016. https://doi.org/10.21831/reid.v2i1.8307

[5] A. Susy Pransiska, Rayandra Asyhar, "Pengaruh Penerapan Model Pembelajaran Group Investigation dan Motivasi Terhadap Hasil Belajar Siswa Kela VII SMP Dalam Pembelajaran IPA Terpadu Pada Materi Asam, Basa dan Garam," vol. 5, no. 2, pp. 1-7, 2016.

[6] M. Darmaji, Astalini, Puspa Armandita, "PENUNTUN PRAKTIKUM VISKOSITAS BERBASIS KETERAMPILAN.” Jurnal Ilmu Pendidikan, 2016.

[7] Siswanto. "Pendidikan Karakter Berbasis Nilai-Nilai Religius". Tadrîs, 8(1). 2013.

[8] Abdulfatah, M. R., Widodo, S. T., \& Rohmadi, M. "Membentuk Karakter Siswa SMA Melalui Karakter Religius Pada Novel Mahamimpi Anak Negeri Karya Suyatna Pamungkas". 3833, 145-152. 2018. https://doi.org/10.21070/pedagogia.v6i1

[9] Noll Jolanda V D. "Religious Toleration of Muslims In the German Public Spher". International Journal of Intercultural Relations .38 60-74. 2014.

[10] Alles, Gregory D. Religious Studies A Global View. London: Routledge. 2018

[11] Darmaji, D. A. Kurniawan, A. Astalini, A. Lumbantoruan, and S. C. Samosir, "Mobile Learning in Higher Education for The Industrial Revolution 4.0: Perception and Response of Physics Practicum," Int. J. Interact. Mob. Technol., vol. 13, no. 09, p. 4, 2019.

[12] Pulungan. F., Huamairah. W., Yanti. H.S. "Pengaruh Religiusitas Terhadap Perilaku Seks Pranikah Remaja Di Prodi D-Iii Kebidanan Jurusan Kebidanan Poltekkes Kemenkes Medan”. Jurnal Ilmiah PANNMED. 13(2). 2018.

[13] Astalini, Maison, Ikhlas. M, \& Kurniawan. D.A. "Pengembangan Instrumen Sikap Mahasiswa Terhadap Mata Kuliah Fisika Matematika". EDUSAINS, , 10(1),46-52. 2018

[14] Sultan, A.D., \& Bancong, H. "Pengaruh pendekatan multiple intelligences melalui model pembelajaran langsung terhadap sikap dan hasil belajar fisika peserta didik kelas XI IPA SMA Negeri 11 makassar". Jurnal Pendidikan Fisika Universitas Muhammadiyah Makassar, 5(1), 51-60. 2017

[15] Darmaji, D. A. Kurniawan, Astalini, and N. R. Nasih, "Persepsi Mahasiswa pada Penuntun Praktikum Fisika Dasar II Berbasis Mobile Learning," pp. 516-523, 2019.

[16] Darmaji, D. A. Kurniawan, Astalini, R. Perdana and D. S. Putra, "A study relationship attitude toward physics, motivation, and character discipline students senior high school, in Indonesia," vol. 11, no. 3, pp. 99-109, 2019.

[17] A. Fitri Karlina, Rayandra Ashyar, and Asrial, "Pengaruh Model PBL Bermedia Muatan Lokal dan Gaya Belajar terhadap Hasil Belajar Siswa pada Materi Klasifikasi Zat di Kelas VII SMP," Edu-Sains J. Pendidik. Mat. dan Ilmu Pengetah. Alam, vol. 3, no. 2, 2014.

[18] A. Astalini, D. Darmaji, W. Kurniawan, K. Anwar, and D. A. Kurniawan, "Effectivenes of Using E-Module and EAssessment,” Int. J. Interact. Mob. Technol., vol. 13, no. 09, p. 21, 2019.

[19] Astalini, Kurniawan. D.A., \& Sumaryanti. "Sikap siswa terhadap pelajaran fisika di sman kabupaten Batanghari". Jurnal Ilmu Pendidikan Fisika. Volume 3 Number. Page 59-64. 2018

[20] A. R. Putri, M. Maison, and D. Darmaji, "Kerjasama Dan Kekompakan Siswa Dalam Pembelajaran Fisika Di Kelas Xi Mipa Sma Negeri 3 Kota Jambi," EduFisika, vol. 3, no. 02, pp. 32-40, 2018.

[21] D. Darmaji, D. A. Kurniawan, A. Suryani, and A. Lestari, "An Identification of Physics Pre-Service Teachers' Science Process Skills Through Science Process Skills-Based Practicum Guidebook,” J. Ilm. Pendidik. Fis. AlBiruni, vol. 7, no. 2, p. 239, 2018.

[22] R. Umilasari and D. Darmaji, "Dominating number of distance two of corona products of graphs," Indones. J. Comb., vol. 1, no. 1, p. 41, 2016.

[23] D. Darmaji, Astalini, D. A. Kurniaawan, H. Parasdila, Irdi, Susbiyanto, Kuswanto and M. Ikhlas, "E-Module Based Problem Solving in Basic Physics Practicum for Science Process Skills," Int. J. Online Biomed. Eng., vol. 15, no. 15, p. 4, 2019.

[24] A. Susy Pransiska, Rayandra Asyhar, end Asrial, "Pengaruh Penerapan Model Pembelajaran Group Investigation dasan Motivasi Terhadap Hasil Belajar Siswa Kela VII SMP Dalam Pembelajaran IPA Terpadu Pada Materi Asam, Basa dan Garam," vol. 5, no. 2, pp. 1-7, 2016.

[25] A. Asrial, S. Syahrial, D. A. Kurniawan, M. Subandiyo, and N. Amalina, "Exploring obstacles in language learning among prospective primary school teacher," Int. J. Eval. Res. Educ., vol. 8, no. 2, pp. 249-254, 2019.

[26] D. A. Asrial, Kurniawan, L. D. Maretika, S. Dasar, and U. Jambi, "Ipa Terhadap Calon Guru Sekolah Dasar Pgsd Fkip,” J. DIDIKA Wahana Ilm. Pendidik. Dasar, vol. IV, no. 2, pp. 41-49, 2018.

[27] D. A. Kurniawan, Astalini, and L. Anggraini, "Evaluasi Sikap Siswa Smp Terhadap Ipa Di Kabupaten Muaro Jambi," Ilm. Didakt., vol. 19, no. 1, pp. 124-139, 2018.

[28] R. K. Dewi, A. Asrial, and B. Hariyadi, "Pengaruh Penggunaan Model Pembelajaran Group Investigasi Bermedia Dan Motivasi Belajar Siswa Terhadap Pemahaman Konsep Biologi," Edu-Sains J. Pendidik. Mat. dan Ilmu Pengetah. Alam, vol. 4, no. 1, 2015. 
[29] Astalini, Kurniawan D. A, \& Farida, L. Z. N. "Deskripsi sikap siswa SMA di Batanghari berdasarkan indikator normalitas ilmuwan, adopsi dari sikap ilmiah, ketertarikan memperbanyak waktu, dan ketertarikan berkarir di bidang fisika". JRKPF UAD , 5(2). 73-80. 2018

[30] Walliman, N. "Research Methods". London : Routledge. 2011

[31] Gay, L.R. “ Educational Research Competencies for Analysis”. Florida International University. 2012

[32] Kothari. C.R.. "Research Methodology Mtehods \& Techniques". New Delhi:NEW AGE INTERNATIONAL (P) LIMITED, PUBLISHERS. 2004

[33] Alison, Mackey. \& Gass,S.M. "SECOND LANGUAGE RESEARCH Methodology and Design". London: Lawrence Erlbaum Associates, Inc. 2005

[34] Darius, Singpurwalla. A Handbook of statistic An overview of statistical methods. London:Bookboon The ebook company. 2017

[35] Kajavinthan, K. “A Study of Religious Attitude among School Students in Jaffna District, Srilank”a. IOSR Journal Of Humanities And Social Science (IOSR-JHSS) .20(7). pp 73-76, 2015

[36] Bintari, N. P., Dantes, N., \& Made Sulastri, M. P. "Korelasi konsep diri dan sikap religiusitas terhadap kecenderungan perilaku menyimpang dikalangan siswa pada kelas XI SMA Negeri 4 Singaraja tahun ajaran 2013/2014”. Jurnal Ilmiah Bimbingan Konseling Undiksha, vol. 2, no. 1. 2014. 